\title{
TEACHING THE CONCEPT OF SINGULARITY AND PLURALITY OF NOUNS WITHIN ENGLISH LESSONS TO CHILDREN OF AN EARLY AGE
}

\author{
Ester Vidović, MSc, lecturer \\ Faculty of Teacher Education, Rijeka (Croatia) \\ e-mail: ester@ufri.hr \\ Morana Drakulić, assistant \\ Faculty of Teacher Education, Rijeka (Croatia) \\ e-mail: morana@ufri.hr
}

\begin{abstract}
S u m m ary
According to the principles of contemporary methods of teaching a foreign language at an early age, grammar is taught with a gradual introduction of its elements through various activities within English lessons in the junior grades of primary school. In the population of junior grade pupils, nouns of irregular plural are one of the grammatical categories the acquisition of which results in frequent mistakes. The most represented method of teaching a foreign language at an early age is the Total Physical Response method (or TPR in short). According to the principles of this method, the foreign language teachers of children of an early age ought to assist their pupils in acheiving several goals: developing listening and speaking skills, including movement in lesson activities and increasing the engagement of the pupils in such activities. All the aforementioned goals can, according to the opinion of the majority of developmental psychologists and ESL methodologists, be realised if the category of plural nouns is taught in combination with children's songs and games, as they are accessible to younger primary school pupils. The aim of this paper is to point towards the importance of the teacher in the proceduralisation phase, i.e. the correction of mistakes that occur due to incorrect plural noun forms, and in particular irregular plural nouns, through songs and games. By combining children's songs and games that include movement and increased participation of pupils, these topics can be efficiently acquired with only a hint of grammatical metalanguage, as the same is only taught in the later phases of learning the English language.
\end{abstract}

Key words: gramar, Total Physical Response Method, proceduralisation, children's songs, games, singular and plural nouns 


\section{Introduction}

The existing multitude of methods for teaching a foreign language greatly differ in their approaches to the acquisition of grammar. As opposed to traditional methods (here the Grammar Translation Method is primarily implied), which insist on the acquisition of grammatical rules and subsequent application of the rules learnt by working through texts and solving grammatical tasks, i.e. which advocate a deductive approach to the acquisition of grammatical content (from the general to the particular), contemporary foreign language teaching methods prefer a completely different approach. According to the principles of these methods, grammar and vocabulary are contemporaneously acquired, while grammar rules are arrived at in an inductive fashion, i.e. from specific examples towards general rules.

The drawbacks of the Grammar Translation Method are, above all, reflected in poorly developed communication skills and, in many cases, passive knowledge of the foreign language at hand found in the individuals who were taught with this method. As a response to the Grammar Translation Method's aforementioned flaws, many new foreign language teaching theories were created in the 1970s and 1980s. These are based on the Communicative approach to teaching a foreign language, i.e. on the promotion of acquiring a foreign language for the purpose of communicating in it. The Total Physical Response Method (or, abbreviated, TPR) has very often been used in English lessons for children of an early age.

\section{The Total Physical Response Method}

This method belongs to the contemporary foreign language teaching methods, deeming the process mechanisms of acquiring a foreign language very similar to those of acquiring a mother tongue. TPR is characterised by methods similar to those applied within the framework of the Direct Method and the Natural Approach Method (Larsen - Freeman, 2000: 107), which consist of stimulating the development of communicative competence. ${ }^{1}$ This method primarily gives importance to the development of the linguistic skills of listening and speaking, and it is precisely for this reason that it is considered one of the most appropriate methods for teaching a foreign language to children of late preschool age or of early primary school age (1st to 4th grade of primary school). An important element in planning activities within foreign language lessons in the vein of the TPR method is the well-known need for movement that young children have. For the reasons stated, it can be concluded that the TPR method is applicable for teaching children aged six to, approximately, ten.

In addition, the natural openness towards communication that children of this age possess in general, and thus also in the context of learning a foreign language,

\footnotetext{
${ }^{1}$ Yvonne Vrhovac supports Dell H. Hymes's definition of communicative competence as "a speaker's ability to, depending on the social situation, select from several language systems the one which suits the situation and the speaker" (Vrhovac, 2000: 15).
} 
ought to be taken into consideration, as should their desire for participating in the teaching process. As opposed to children of pubescent age (from the age of 12 onwards) and adults, who are inhibited by an (overly) self-critical stance towards their language skills or by the possibility of being mocked by their peers, there are, generally, no such obstacles for children aged up to twelve (Cameron, 2001). One of the advantages of learning a foreign language at an early age is certainly the sensitivity of the listening apparatus in the children of pre-pubescent age. Research points towards the fact that younger children are able to acquire the correct pronunciation and intonation better, while older children, i.e. teenagers and adults, acquire grammar faster (Moon, 2005: 17), which can be attributed to the fact that children of pubescent age or older individuals are already acquainted with the grammatical metalanguage of their mother tongue, that is, the expressions with which grammatical categories are described. According to the TPR method, listening and speaking skills ought to be developed gradually: in the first stages of the activities conducted in accordance with the TPR method, children first listen to directions in a foreign language and react to them with the action/movement expected from them, while in the later stages of these activities the pupils' input is increased, and they gradually begin to take on the role of the teacher in the sense of giving orders to other pupils (Cameron, 2001:107).

Grammar is, in the context of the TPR method, introduced in an inductive fashion: TPR, in fact, advocates the acquisition of a foreign language without the formal instruction of grammar. Children encounter many examples of grammatical categories and acquire them through play, song, rhyme and many other lesson activities, both guided and independent. The formal acquisition of grammar rules is left for the more advanced and formal stages which the pupils encounter later. The TPR method primarily develops the linguistic skills of listening and speaking, while only tackling reading and, finally, writing, in later stages. The methodologist Lynne Cameron believes that children are able to acquire grammatical metalanguage already at an early age, however, she recommends its use at later stages of learning, deeming that children of an early age have not yet even mastered the grammatical metalanguage of their own mother tongue. (Cameron, 2001: 106).

\section{Defining Grammar}

Cameron gives a simplified definition of grammar as the system of a particular language, i.e. the aspects of its use (Cameron, 2001: 98). The author differentiates between theoretical, pedagogic and "inner" grammar.

Theoretical grammar deals with describing the patterns of the use of a particular language. According to the principles of Noam Chomsky's generative grammar language is, like grammar, innate. According to generativists, grammar deals with researching the syntactic similarities between languages and as such, deems Cameron, has no value applicable to teaching (Cameron, 2001: 99). As opposed to the generativists, Hallyday's linguistic circle, creators of the concept of functional grammar, perceives grammar as a means of expressing opinions. In 
addition, grammar systems based on studying the corpus of grammar, the research matter of the so-called corpus linguists, have also been playing an important role as of recent. (Cameron, 2001: 100).

Theoretical grammars are not appropriate for teaching, which is why they were remodelled and adapted to lessons, thus creating the so-called pedagogic grammars. These grammars directly explain the patterns, i.e. rules of a language, and are of great assistance to both teachers and students. As opposed to teachers, who ought to be acquainted with a thorough overview of the grammar of the language they are teaching, students acquire the grammar content part by part, and usually in the same order and fashion as offered in the textbooks used in lessons.

"Inner" grammars are, in fact, grammars that are acquired individually, that is, every individual acquires them in their own specific way, while they are also sometimes defined as an interlanguage or linguistic competence. Every individual creates his/her own inner grammar, i.e. creates a system of linguistic rules according to their own understanding of grammatical categories (Cameron, 2001: 100). Understanding how this type of grammar functions in an individual is of exceptional importance to every teacher in order to obtain quality feedback, spot differences in teaching and learning and approximate grammar to each student as much as possible.

\section{The Sequences of Activities in the Acquisition of Grammatical Material in a Foreign Language}

Cameron holds that the grammar of a foreign language, as opposed to that of the mother tongue, ought to be taught systematically, i.e. that foreign language teachers ought to assist the children first in noticing, and then in acquiring grammatical patterns, all for the purpose of creating an individual "inner" grammar in each pupil/child. (Cameron, 2001: 108).

The author advocates sequences of activity phases through which a child of an early age creates his/her own "inner" grammar according to specific patterns and structures (Cameron, 2001: 108):

1st phase: noticing

2nd phase: structuring

3rd phase: proceduralising

In the first phase, children begin to notice structures and the connections between form and meaning, but do not yet use language personally. Form is noticed as an isolated shape, but also as part of discourse and linguistic context, and is compared to the forms that are already familiar. In this phase, children often notice chunks of language, that is, phrases that they acquire and later use in speech in their entirety e.g.: I don't know, Come on, Goodbye, etc. (Moon, 2005: 6). Activities characteristic for the noticing phase gradually grow into activities of the second phase, the structuring phase, i.e. those activities during which pupils already freely manipulate with a foreign language. In this sense, the aforementioned expressions 
can be splintered and combined with other linguistic elements, such as: We don't know, I don't know his name, while transformation in the relation between the subject and the predicate also occurs in later stages, such as in the example $\boldsymbol{H e}$ doesn't know ( Moon, 2005: 6). Grammar mistakes are not made seldom in this phase, occuring due to the fact that children here apply the acquired grammatical patterns in new situations. In this manner, the Simple Past of the irregular verbs make and take can, instead of made and took, result in the forms maked and taked, created according to the model by which regular verbs form Simple Past. In the third stage, i.e. the proceduralisation stage, an automatisation in the use of most grammatical forms occurs. In this process, the role of the teacher is of immeasurable significance, as in this phase the mistakes characteristic of the second phase of creating an "inner" grammar are corrected, in the manner of adapting the demanding character of certain activities and shortening the time allotted for various activities in class (Cameron, 2001: 109).

\section{The Acquisition of Grammar in the Mother Tongue}

Many linguists have studied, and are still studying the mechanisms of the acquisition of the mother tongue. The grammar of every language is composed of three segments: syntax (word order), inflection (declension and conjugation) and intonation (stress). According to Bates and MacWhinney's Competition Model, children test grammatical elements, such as word order, intonation and suffixes at an early age, opting for that symbol for which they believe will be of the greatest use to them in learning the linguistic structure of their mother tongue (Vasta, Haith, Miller: 1998: 429). The symbols selected often vary from language to language, and their relevance may change according to the child's age: in the inital stage, children select the symbol that is the most accessible (in English and French this is, for example, the word order in a sentence), while in the second phase the children focus on the most reliable symbols, i.e. those that explain the structure of grammar in the most consistent way and, finally, in the third phase they notice symbols that are in collision, after which they opt for those symbols that best reflect the structure of the language (Vasta, Haith, Miller, 1998: 429).

The acquisition of the system of the mother tongue can be divided into several phases: the phase between the twelfth and twenty-fourth month of life is characterised by the usage of expressions composed of only one word which have multiple uses, thus the word ball can be used in order to name the object or to demand the same object. The phase of using one word gradually proceeds into the phase of using two words separately in order to describe an object ("Milk - hot") and then, at the age of approximately two, into short sentences of two or three words, in which the application of syntactic rules first occurs as in building around certain words ("No mum.", "No dog".). In the next phase, i.e. the phase of telegraphic speech, the sentences are extended to four of more words and, by leaving out functional words such as prepositions or articles, or parts of words such as suffixes, appear similar to telegram messages, for example a two year old could realise the 
sentence "Billy, let's go to the party" as "Billy go party" (Vasta, Haith, Miller, 1998: 425).

Soon mistakes similar to those that happen during the acquisition of a foreign language begin to occur, i.e. mistakes in the use of the past tense of irregular verbs appear in children's speech - in those to which the suffix $-d$ or $-e d$ is not added (eg. the verbs take - took, make - made, go - went etc.) and in nouns whose plural is not created by adding the suffix $-s$ or -es (tooth - teeth, foot-feet, mouse - mice, etc.). According to some authors, children do not have to necessarily use incorrect forms of words consistently: the same child may sometimes use the correct form, eg. mice (plural of mouse), while in other cases excessive generalisation (in this case, the application of the suffixes of regular plural nouns onto irregular plural nouns) results in the form mouses (Vasta, Haith, Miller, 1998: 426).

If we compare the phase of the acquisition of grammatical elements of mother tongue just described to the structuring phase that occurs during the acquisition of a foreign language, it can be concluded that there are many similarities between them. Mistakes most often occur in the use of the same grammatical categories (noun plurals, Simple Past) in a similar way (excessive generalisation, the inconsistent use of regular and irregular word forms). One of the reasons due to which the aforementioned mistakes occur is certainly imitation. Children of an early age primarily imitate the speech of their parents, as they spend the most time with them (Vasta, Haith, Miller, 1998: 430). Children can emulate an expression they have just heard by adding something to it, which results in delayed imitation, while they often also imitate in an unselective fashion, i.e. by copying the linguistic structure but using different words.(Vasta, Haith, Miller, 1998: 431).

The third phase of the acquisition of a foreign language, i.e. the proceduralisation phase, finds its equivalent in the support mechanisms in the acquisition of the mother tongue. As opposed to the teacher who, in the process of teaching a foreign language, directs pupils towards the correct use of a particular grammatical category, in the acquisition of the mother tongue the parents are those who give feedback (or negative evidence) to their child. Vasta, Haith and Miller (1998: 431) point towards research results according to which mothers react to their children's incorrectly formulated questions in three ways: with expansion (repeating the child's sentence "Mouses runs along the corridor" in a correct and more complete fashion eg. "Yes, the mice are running along the corridor"), correction (the child's sentence is repeated with a change in structure eg. "Are the mice running along the corridor?" or with a clarifying question (questions that show the child that the listener has not received the message and stimulate the child to communicate again, eg. in the questions "What's going on?, What are the mice doing?").

In the previous part of the text, we have indicated the grammatical categories in which children frequently err in the acquisition of grammar content in the English language, i.e. the categories of irregular noun plurals and the Simple Past tense). Considering that the work focuses on teaching grammar to children of an early age, we have limited ourselves to the grammatical category of noun plurals which is, chiefly, introduced very early in the process of teaching English at an early age. In 
addition, we must also stress that instruction relating to these categories is largely present within the various activities that are implemented in English lessons for children of an early age, and primarily in children's songs and games. In the further text, we shall attempt to consolidate previous knowledge and cognisance regarding the problem of teaching the category of noun plurals in English lessons for children of an early age, and also to offer initiatives to aid junior grade pupils in overcoming difficulties regarding the acquisition of these grammatical categories.

\section{The Concept of Singularity and Plurality}

Research indicates that children who are only several weeks old already begin to comprehend the world around them and to communicate with other individuals in the outside world, which is primarily manifested in imitation of the facial expressions of adults. Children aged up to one perceive the world in an egocentric fashion, commencing from themselves as a starting point, thus at least partially demonstrating consciousness of their own existence (Vasta, Haith, Miller, 1998: 493). By familirising himself/herself with the world, the child also acquires the concept of singularity and plurality, i.e. it is surrounded by single, but also identical objects. The process of self-recognition begins somewhat later: it is a common thought that a child is able to confidently recognise his/her own self at the age of 24 months (Vasta, Haith, Miller: 1998: 494). During this phase, children gradually begin to recognise their own reflection in the mirror and to spot their body parts, thus attaining the knowledge that they have one head and one mouth and lips, but two legs, two arms and a pair of eyes and ears.

If instruction of a foreign language is to begin at this age, which is not a rare occurence (we are witnesses to an increasingly early exposure of children to foreign languages in schools/play groups that include a programme in a foreign language, bilingual families and extended families, nannies that teach children their own mother tongue, etc.), the anatomy of the human body can serve as the ideal context for teaching the concept of the singularity and plurality of nouns. For this purpose, children's songs and games can be efficiently used within English lessons.

\section{Songs and Games in the Function of Teaching the Grammatical Category of the Singularity and Plurality of Nouns}

From the abundance of activities between which an English teacher can choose regarding the instruction of grammatical categories, songs and games may perhaps seem the most appropriate due to their appeal. These activities contribute to breaking the monotony of lessons, can be easily linked with kinetic activities and stimulate creativity as they offer the option of implementing various activities in class (Vidović, 2008: 495). 


\section{Children's Songs}

The benefit of children's songs is manifold: in addition to the pleasure derived from singing, the children memorise a song easier thanks to the rhythm and rhyme, in the process acquiring new vocabulary and grammatical structures without even being aware of it (Vidović, 2008: 495). Guy Cook points toward the universality and omnipresence of rhythm: we encounter rhythm already in our mother's uterus, listening to the beating of her heart and, later, while suckling and rocking in her lap; afterwards, rhythm attains a social character in dance, individual or group song, poetry, etc. (Cook, 2000: 22). Rhyme is equally important as it aids in memorising the words and predicting the text of the song if one has not managed to master it well yet. Repetition also plays an important role in the introduction of grammatical structures, in this case the category of the singularity and plurality of nouns, as children acquire a pattern that is later repeated in other elements within the song.

The song "Head and Shoulders" is appropriate in the context of learning English at an early age for many reasons: due to the fact that the children in question are of early primary school age and have only been learning English as a foreign language for a short time it is a good choice thanks to its shortness, simplicity, repetition and regular rhythm. This song is also a good source for acquiring new vocabulary pertaining to the human body. One other reason for selecting this song is its saturation with grammatical structures, that is, with singular and plural nouns. In order to attain insight into the usability of the song, primarily relating to teaching the grammatical categories of singular and plural nouns, we quote its most popular verse:

\section{Head and shoulders, knees and toes, knees and toes \\ Head and shoulders, knees and toes, knees and toes \\ Eyes, and ears, and mouth and nose \\ Head and shoulders, knees and toes, knees and toes.}

In this song, children encounter singular (head, nose, mouth) and plural (shoulders, knees, toes, eyes, ears) nouns and have the opportunity to apply their knowledge on body parts (how many ears, mouths, knees etc. we have) in a foreign language, as well. The plural of these nouns is formed with the addition of the suffixes $-s$ (shoulder, ear) and -es (knee, toe, eye) and through their constant repetition the children spot and memorise these forms, while in later phases they are also, by invoking the already acquired plural noun forms, able to arrive to generalisations relating to the formation of noun plurals. Grammatical parallelism also helps in this generalisation process, pointing towards the repetitive nature of particular components, in this case chunks of language such as knees and toes and eyes and ears. Furthermore, the children inductively conclude that the plural of most nouns in the English language is formed by adding the suffix $-s$, and a smaller number with the suffix -es, including nouns that end with the vowel $e$.

This poem is also appropriate for teaching children of an early age as singing can also be accompanied by movement. Conversation can be preceded by listening 
to the song from a $\mathrm{CD} /$ tape recorder while the children observe the teacher who motions towards his body parts, gradually involving the little listeners in active participation accompanied by the corresponding movements, with the children contemporaneously singing and indicating their body parts and, finally, singing the song independently. One of the activities can also be engaging one child to point out his/her body parts, and the others to sing. The activities listed are completely in accordance with the stages of the TPR method, which is focused on gradually including children and increasing their participation, while decreasing the engagement of the teachers concerning various activities in foreign language lessons that include motion.

Grammatical parallelisms offer teachers the option of tackling the complexity within particular grammatical categories. The song "Here We Go 'Round the Mulberry Bush" introduces actions related to morning ablutions: washing the hands and face, brushing teeth, combing etc. Due to the length of the song, we are going to quote only two verses:

This is the way we wash our face

Wash our hands, wash our face

This is the way we wash our face

So early in the morning.

This is the way we brush our teeth

Clean our teeth, brush our teeth

This is the way we brush our teeth

So early in the morning.

The expressions describing the actions contain nouns that form regular plurals (...we wash our face), but also those that form irregular plurals (...we brush our teeth) and those that have only the singular form (... we comb our hair, ...we eat our breakfast). From the example given, it is evident that the song introduces the irregular plural of nouns (without the suffixes -s/-es: teeth) and nouns that are usually used in their singular form, i.e. singularia tantum (hair, breakfast). If these nouns are already familiar to the pupils from previous activities, that is, if the teacher has already introduced irregular plurals through the example of foot - feet, the pupils can imply the form teeth as the plural of the noun tooth through grammatical parallelism.

One of the efficient activities for the acquisition and proceduralisation of the grammatical category of the plurality of nouns can also be a filling in exercise. The song can be shown to the pupils in an incomplete version with nouns missing at the end of every line or in the middle of the line:

This is the way we wash our

Wash our , wash our

This is the way we wash our

So early in the morning. 
With the aid of grammatical parallelism, the pupils will fill in the text of the song with both regular plural forms and, if they have been introduced in one of the previous activities, irregular verb forms. Some of the options for introducting the category of irregular plural nouns will be presented later in the text.

With the aim of realising the proceduralisation phase as successfully as possible, the teacher can try to introduce a grammatical metalanguage through questions that he poses to the pupils after introducing examples of irregular plural nouns. Cameron (2001: 120) quotes some of the possible questions:

Examples for regular plurals:

"T: If we have many of them ... two of them?

P: cows

T: horse

P: horses"

Examples for irregular plurals:

"T: sheep?

P: sheep

T. yes (.) we don't put the s at the end of sheep

T: wolf

P: W..O..L..F..S

T: you should ( I.O) one should think so ( . ) but ( . ) it isn't so (2.O) yes?

P: W..O..L..V..E..S

T. yes (I.O) yes (I.O) it's a special word (2.O)

one wolf $($.$) with \mathrm{F}$

two wolves ( . ) with $\mathrm{V}^{\prime \prime}$

Cameron also gives an example of plurals in which a change of consonant occurs (wolf-wolves), however, it remains for every teacher to decide in which forms and on what level can the pupils be acquainted with a grammatical rule.

In order to avoid automatism in the production of plural nouns and to completely distinguish the singular category from the plural category, the pupils can be made to think about the decision which form to choose. The song "Ten Little Indians" can serve as a good example:

John Brown had a little Indian,

John Brown had a little Indian,

John Brown had a little Indian,

One little Indian boy.

One little, two little, three little Indians,

Four little, five little, six little Indians,

Seven little, eight little, nine little Indians, 


\section{Ten little Indian boys.}

In singing the second verse in reverse, errors in grammatical form often occur due to inertia: instead of the singular form (One little Indian boy), the pupils use the plural form (One little Indian boys or even One little Indians boys). By frequently singing the song in reverse the pupils will, with the guidance of a teacher indicating mistakes, acquire the correct form of singular and plural nouns.

\section{Games}

Play is considered one of the most efficient didactic activities in class, regardless of whether it includes the presence of adults. Certain authors deem this view rash, explaning their stance with the lack of empirical research to explicitly confirm the efficacy of play in class (Bennett, Wood, Rogers, 1997: 4). Pellegrini suggests a definition of play according to which it would be composed of three elements: disposition, context and observable behaviour. According to the author, disposition includes intrinsic motivation, attention, exploration, nonliteral behavior, flexibility and active engagement, while the context is usually familiar, stress-free and involves freedom of choice (Bennett, Wood, Rogers, 1997: 4). The last element of play, observable behaviour, is based on Jean Piaget's theory on the three stages of play: functional play, symbolic play and play with rules, which are developed during early childhood (Bennet, Wood, Rogers, 1997: 5).

Pupils perceive play differently than teachers do: while children see play without the elements of learning, the teachers perceive it in the context of the learning topic they are teaching (Bennett, Wood, Rogers, 1997: 3). According to the aforementioned authors, theoreticians of developmental psychology do not have a unanimous stance on the inclusion of teachers in the play of children: while some theoreticians advocate the stimulation of free play, with minimal engagement from the teacher (Susan Isaacs, Maria Montessori) or giving him/her an observational role (Jean Piaget), constructivists promote the idea of interaction between pupils and teachers, in which the latter, armed with their knowledge, assist the pupils in the acquisition and consolidation of knowledge (Jerome Bruner, Lev Vygotsky). Recently, it seems, theoreticians of children's psychology and pedagogy have been stressing not only the importance of the content of a game, but also the skills and learning outcomes developed through play.

\section{Play in the Context of Teaching the Singularity and Plurality of Nouns in English Lessons to Children of an Early Age}

There are many games that possess potential for the introduction and practice of the grammatical category of plural nouns. One of them is also the memory game, which can be played either with ready-made cards or cards specially created for the purposes of the lesson. Children are usually acquainted with this game already at preschool age as well as with the rules of the game. The game consists of a set of cards (pictures) where every card has its pair: houses, cars, wheels etc. appear in 
pairs. Some versions of this game contain only pictures of the object or expression, while in other versions every picture without text has its pair in a picture that, underneath the drawing, also contains the word in its written form, sometimes also including a phonetic transcription, which can serve as additional practice of the various sounds with which the plural forms of particular nounds end, eg. cars [ka:z], rat [rats] etc. The cards are arranged with the pictures face-down, and the goal is to guess as many pairs as possible by flipping the cards to the side showing the picture. A rule according to which the pupils, while turning over the cards, must also state the singular and plural form of the noun represented by the card, additionally accelerates the acquisition of the patterns of noun formation. One of the versions of this game includes sorting the cards on the board into rows provided for nouns in singular and plural.

As previously stated, the teacher may also introduce the category of irregular plural nouns through play, reiterating them through song or other activities in class. In this manner, cards that include pairs representing irregular plural nouns (eg. tooth - teeth, foot - feet, mouse - mice, etc.) may be specially created. After irregular plural nouns are introduced in this fashion, they may be additionally practised through other classroom activities, including children's songs.

One such activity is also back writing. This game is recommended by methodologist Mario Rinvolucri for multiple reasons, primarily for consolidating vocabulary and practising grammatical categories in which there are pairs among its constituents, eg. Infinitive - Past Simple, names of countries - names of languages, collocations, etc. Rinvolucri suggests several phases of the game. In the first phase, the teacher splits the group into pairs. One of the pupils in the pair writes the singular form of an irregular noun on the back of his/her colleague, while the task of the colleague is to "read" the noun on his/her back and write the plural of the same on his/her colleague's back. Follows a phase in which the teacher gives the pupils cards that contain a singular or plural noun follows, while the pupils' task is to sort each singular/plural words into the corresponding row on the board, i.e. to sort each card into the row for singular nouns or the row for plural nouns (Rinvolucri, 2000: 121-122).

Apart from practising irregular plural nouns, English lessons for children of an early age can also implement games that introduce collective nouns. One such game is Fruit Salad. The rules of the game are simple: the pupils sit in a circle and each is assigned the name of a fruit: a banana, a cherry, an apple, an orange, a strawberry, and then again a banana, a cherry, etc., until the last pupil is assigned the name of a fruit. The teacher stands in the circle and calls for the pupils assigned to one fruit (eg. Apples!) to switch places. Since the teacher does not have a chair and is standing in the middle of the circle, during this switch he has to find himself a seat, which means that one chair is missing in the circle. The pupil that remains without a chair gives the next order. If the teacher or pupil giving the order wishes for all pupils to switch places, he shouts: Fruit salad! This game can also be conducted using the names of animals, while in this version the command for all participants to switch chairs is: Zoo! (Čajo, Knezović, 2003:99). 
All the aforementioned games involve movement and can be implemented in class within the TPR method. They stimulate the development of the linguistic skills of speaking and listening, which is also in accordance with the basic principles of the TPR method. Finally, an increase in the pupils' activity and a decrease in the teacher's engagement is evident in all the games proposed and described. It can be concluded that all the games mentioned are applicable to English lessons for children of an early age.

\section{Conclusion}

According to contemporary approaches to teaching English to children of an early age, and particularly according to the principles of the TPR method, grammar is not to be taught with the introduction of rules, but rather with its elements gradually introduced through various activities in class. Thus children's songs and games may find their place in classes, facilitating the aquisition of grammar content due to their casual nature: songs due to their melody, rhythm, repetition and rhyme, and games because of the space they give children by increasing their participation in the game and giving them an opportunity to express their creativity. Observing the world around him, a child acquires the concept of singularity and plurality during the second year of his life. Nouns of irregular plural are one of the grammatical categories in which children most frequently make mistakes during the acquisition of both the mother tongue and a foreign language. The formation of regular plural nouns does not usually represent a problem either in the mother tongue or in a foreign language. Deviations from the rules of forming nouns in plural, that is, plural formation without the suffix $-\mathrm{s} /$-es often results in mistakes in children's speech.

Grammatical content is acquired through three phases: noticing, structuring and proceduralising. In the proceduralisation phase, the teacher's role is to assist in the acquisition of the correct forms of nouns forming irregular plural. By combining children's songs, games that involve movement and an increase in the children's participation, this content can be successfully acquired with only a hint of grammatical metalanguage, as it is systematically taught only in the later phases of learning the English language.

\section{Bibliography}

Bennet, N.; Wood,L; Rogers,S. (1997);Teaching through Play: Teachers'Thinking and Classroom Practice; Open Universtiy Press; Hong Kong Cambridge

Cameron, L.(2001); Teaching Languages to Young Learners; Cambridge University Press;

Cook, G. (2000); Language Play, Language Learning; Oxford University Press; Hong Kong 
Čajo, K.; Knezović, A. ( 2005); Building Blocks 3: Teacher’s Book: priručnik za učiteljice/učitelje engleskog jezika za 3. razred osnovne škole uz udžbenik Building Blocks 3; Profil; Zagreb

Larsen - Freeman, D.( 2000); Techniques and Principles in Language Learning; Oxford University Press, Hong Kong

Moon, J. (2005); Children Learning English; Macmillan; Thailand

Rinvolucri, M. (2000); Grammar Games; Cambridge University Press; Cambridge

Vasta, R.; Haith, M.M.; Miller, S.A. (1998); Dječja psihologija; Moderna znanost, Zagreb

Vidović, E. (2008); Učenje engleskog jezika u ranoj dobi pomoću pjesmica; Učiteljski fakultet Sveučilišta u Zagrebu; Zagreb

Vrhovac, Y. (2001); Govorna komunikacija i interakcija na satu stranoga jezika; Naklada Ljevak; Zagreb

\title{
Websites:
}

www.songsforteaching.com/folk/herewegoroundthemulberrybush.htm

www.beaconlearningcenter.com/documents/5396_4695.pdf

www.nurseryrhymes4u.com/NURSERY_RHYMES/Page_57.htm

Metodički obzori 7(2012)2

Pregledni rad

UDK: 811.111'36:373.32

Primljeno: 1. 11. 2010.

\section{POUČAVANJE KONCEPTA JEDNINE I MNOŽINE IMENICA U NASTAVI ENGLESKOGA JEZIKA U RANOJ DOBI}

\author{
mr. sc. Ester Vidović, predavač \\ Učiteljski fakultet u Rijeci \\ e-mail: ester@ufri.hr
}

Morana Drakulić, asistent Učiteljski fakultet u Rijeci e-mail: morana@ufri.hr

\section{Sažetak}

Gramatika se, prema načelima suvremenih metoda poučavanja stranoga jezika u ranoj dobi, poučava postupnim uvođenjem elemenata gramatike putem raznovrsnih aktivnosti u nastavi engleskoga jezika u mlađim razredima osnovne škole. Gramatička kategorija čije usvajanje rezultira učestalim greškama u populaciji učenika nižih razreda osnovne škole jest množina imenica nepravilne tvorbe. Najzastupljenija metoda u poučavanju stranoga jezika u ranoj dobi je metoda poučavanja pokretom (Total Physical Response, skraćeno TPR). Prema načelima ove metode nastavnici stranoga jezika u ranoj dobi trebali bi pomoći 
učenicima u ostvarivanju nekoliko ciljeva: razvijanju vještina slušanja i govorenja, uključivanju pokreta u aktivnosti u nastavi i povećanju učeničkoga angažmana u raznovrsnim aktivnostima. Svi navedeni ciljevi mogu se, prema mišljenju većine razvojnih psihologa kao i metodičara nastave engleskoga kao stranoga jezika/ engleskoga za govornike drugih jezika, ostvariti ako se kategorija množine imenica proučava u kombinaciji pjesmica i igara, koje su pristupačne djeci mlađe osnovnoškolske dobi. Cilj ovoga rada jest upućivanje na važnost nastavnika u fazi proceduralizacije, tj. ispravljanju pogrešaka do kojih dolazi uporabom pogrešnih oblika imenica u množini, naročito kod imenica nepravilne tvorbe, i to putem aktivnosti koje uključuju igru i pjesmu. Kombinacijom pjesmica i igara koje uključuju pokret i povećano sudjelovanje učenika, ovi se sadržaji mogu učinkovito usvajati tek s naznakama gramatičkog metajezika, s obzirom da se on sustavno poučava u kasnijim fazama učenja engleskoga jezika.

Ključne riječi: gramatika, metoda poučavanja pokretom, proceduralizacija, pjesmica, igra, jednina i množina imenica 